Provided for non-commercial research and education use. Not for reproduction, distribution or commercial use.

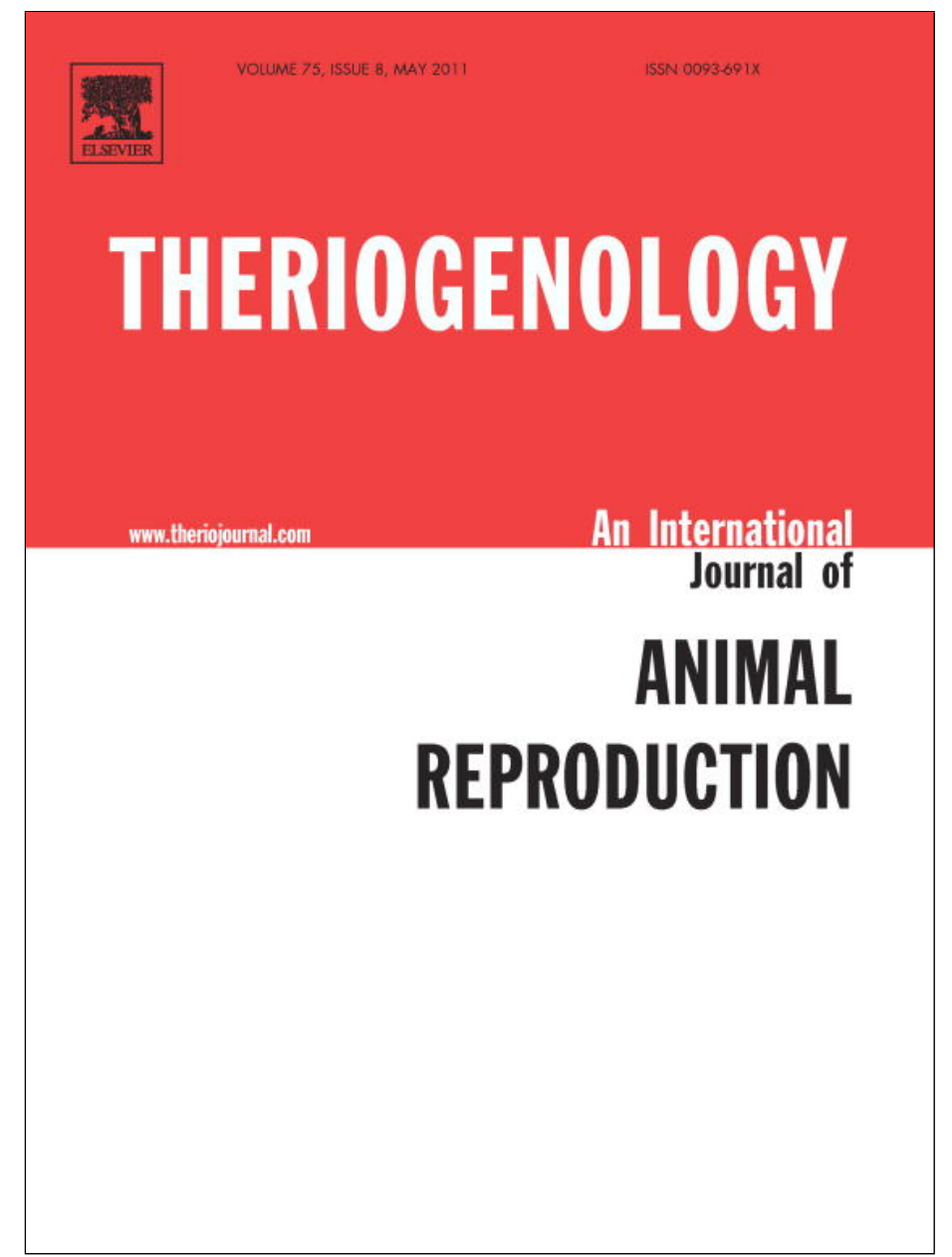

This article appeared in a journal published by Elsevier. The attached copy is furnished to the author for internal non-commercial research and education use, including for instruction at the authors institution and sharing with colleagues.

Other uses, including reproduction and distribution, or selling or licensing copies, or posting to personal, institutional or third party websites are prohibited.

In most cases authors are permitted to post their version of the article (e.g. in Word or Tex form) to their personal website or institutional repository. Authors requiring further information regarding Elsevier's archiving and manuscript policies are encouraged to visit:

http://www.elsevier.com/copyright 


\title{
Large animal models for cardiac stem cell therapies
}

\author{
F. Gandolfi*, A. Vanelli, G. Pennarossa, M. Rahaman, F. Acocella, T.A.L. Brevini \\ Laboratory of Biomedical Research, Centre for Stem Cell Research, Università degli Studi di Milano, Via Celoria 10, 20133 Milano, Italy \\ Received 20 August 2010; received in revised form 18 January 2011; accepted 23 January 2011
}

\begin{abstract}
Cardiovascular disease is the leading cause of death in developed countries and is one of the leading causes of disease burden in developing countries. Therapies have markedly increased survival in several categories of patients, nonetheless mortality still remains high. For this reason high hopes are associated with recent developments in stem cell biology and regenerative medicine that promise to replace damaged or lost cardiac muscle with healthy tissue, and thus to dramatically improve the quality of life and survival in patients with various cardiomyopathies.

Much of our insight into the molecular and cellular basis of cardiovascular biology comes from small animal models, particularly mice. However, significant differences exist with regard to several cardiac characteristics when mice are compared with humans. For this reason, large animal models like dog, sheep and pig have a well established role in cardiac research. A distinct characteristic of cardiac stem cells is that they can either be endogenous or derive from outside the heart itself; they can originate as the natural course of their differentiation programme (e.g., embryonic stem cells) or can be the result of specific inductive conditions (e.g., mesenchymal stem cells). In this review we will summarize the current knowledge on the kind of heart-related stem cells currently available in large animal species and their relevance to human studies as pre-clinical models. (C) 2011 Elsevier Inc. All rights reserved.
\end{abstract}

Keywords: Sheep; Pig; Dog; Animal model; Heart

\section{Contents}

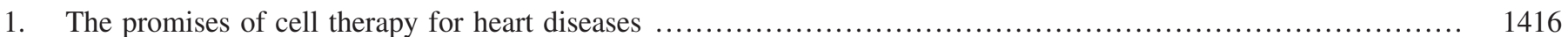

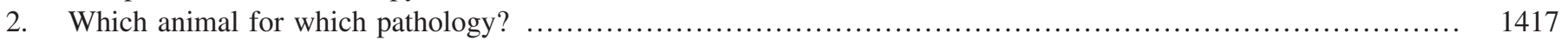

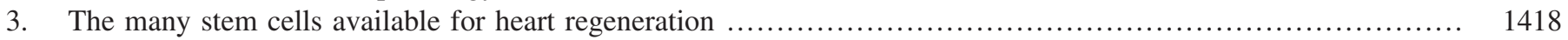

4. Which cardiac stem cells are available in large animal models, and do they actually work? ........................1419

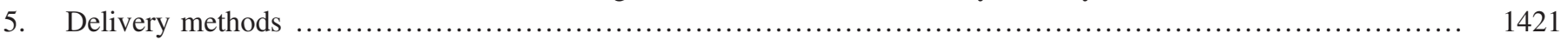

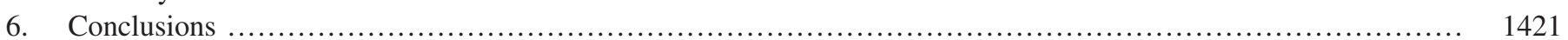

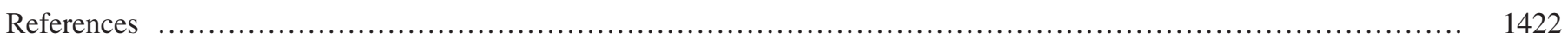

\section{The promises of cell therapy for heart diseases}

Cardiovascular disease is the leading cause of death in developed countries and is one of the leading causes

\footnotetext{
* Corresponding author. Tel.: 39025031 7990; fax: 390250317980

E-mail address: fulvio.gandolfi@unimi.it (F. Gandolfi).
}

of disease burden in developing countries [1,2], severely affecting quality of life and decreasing life expectancy. It is a consequence of ischemic and nonischemic cardiomyopathies, usually associated with left ventricular dysfunction. A rising heart failure incidence is associated with unhealthy lifestyles and increasing population age. Current therapies are essentially symp- 
tomatic and, even though they provide some survival benefit, they cannot reverse the loss of contractile cardiac tissue due to ischemic injury.

For this reason high hopes are associated with the recent developments in stem cell biology and regenerative medicine that promise to replace damaged or lost cardiac muscle with healthy tissue, and thus to dramatically improve the quality of life and survival in patients with various cardiomyopathies.

Until a few years ago, this was considered impossible, as the heart was thought to be an organ composed of terminally differentiated myocytes incapable of regeneration. Indeed, this can still be hard to believe based on everyday experience, which indicates a grossly inadequate regenerative capacity of human myocardium to compensate for the loss of heart muscle presented by myocardial infarction or other myocardial diseases.

However, evidence creates the general consensus that transplantation of progenitor cells of different origin can theoretically improve ventricular function after injury [3], although whether or not current in vitro and animal studies provide enough evidence to warrant clinical trials is hotly debated.

Much of our insight into the molecular and cellular basis of cardiovascular biology comes from small animal models, particularly mice. However, significant differences exist with regard to several cardiac characteristics when mice are compared with humans [4].

An important parameter is heart rate, with an adult mouse heart beating 500-600 times per minute, compared with the 60-100 times typical of the human. This extends to other functional parameters summarized in Table 1.

Apart from size, human and murine hearts differ in coronary architecture, the variations of which are much bigger in humans compared with mice. As a consequence, whereas the size and location of the ischemic area are fairly constant in the mouse, a much larger variation exists in the human [5]. Differences can also be appreciated at the cellular level,

Table 1

Comparison of indicative anatomy and physiology data between human and the most common heart disease animal models

\begin{tabular}{lccr}
\hline Species & $\begin{array}{c}\text { Heart } \\
\text { weight }\end{array}$ & $\begin{array}{c}\text { Heart rate/ } \\
\text { min }\end{array}$ & Systolic pressure \\
\hline Human & $360-480$ gr & $60-90$ & $60-120 \mathrm{~mm} \mathrm{Hg}$ \\
Mouse & $0.14-0.15$ gr & $500-600$ & $80-160 \mathrm{~mm} \mathrm{Hg}$ \\
Rabbit & $9-11 \mathrm{gr}$ & $120-300$ & $70-170 \mathrm{~mm} \mathrm{Hg}$ \\
Dog & $160-420 \mathrm{gr}$ & $60-120$ & $120-150 \mathrm{~mm} \mathrm{Hg}$ \\
Pig & $400-500 \mathrm{gr}$ & $65-75$ & $70-130 \mathrm{~mm} \mathrm{Hg}$ \\
Sheep & $240-360 \mathrm{gr}$ & $70-80$ & $80-120 \mathrm{~mm} \mathrm{Hg}$ \\
\hline
\end{tabular}

as indicated by the higher capillary density observed in the mouse than in the human heart and by the larger cross sectional area of the myocytes in the human than in the mouse [6,7].

Important differences continue at the molecular level: humans have a high level of $\beta$-myosin heavy chain isoform, whereas mice have a high level of the $\alpha$-myosin heavy chain isoform compared with the total myofibrillar myosin protein in the ventricles $[8,9]$. This, in turn suggests a possible difference in the mechanical behavior of the myocardium between the two species [10].

Consequently, extrapolation of murine systems, particularly after induction of cardiovascular stress, has some obvious limits that can be crucial the closer it gets to a clinical application.

Therefore, it is generally acknowledged that large animal models, which more closely approximate human physiology, function and anatomy, are essential to develop the discoveries from murine models into clinical therapies and interventions for heart therapies [4].

Here we review the advantages and limitations of using large animal models when attempting to bridge the gap between new basic science discoveries in stem cell research and their translation into new clinical treatments.

\section{Which animal for which pathology?}

We have briefly mentioned that human and mouse heart present some important differences but it must be said that the so called large animal models are an heterogeneous group and, as such, there is no single perfect animal model (Table 1).

Dogs are becoming an increasingly popular model due to their behavior and ease of handling. Investigations on myocardial ischemia and infarction have historically relied on observations performed on adult dogs, leading to the identification of fundamental parameters such as the time course to myocite irreversible injury with increasing period of ischemia moving from endocardium towards the epicardium [11]. Research on dogs built the foundation on which current reperfusion treatment guidelines for acute coronary syndromes were developed and provided proof of concept for thrombolytic therapy. Physiological similarities with humans extend to the endocrine system enabling the study of the cardioprotective effect of drugs modulating the renin-angiotensin pathway [12]. However relation between heart size and body weight in the dog compared to human is almost twice and, on the other hand, 
dog heart has a collateral coronary circulation approximately four times more extended than that of man, making it difficult to obtain a consistent degree of myocardial injury following experimental ischemia and to reliably extrapolate to human the post-infarction course observed in dogs [13].

Pig seems to differ from man in its predisposition for refractory arrhythmogenesis, providing an altered response to myocardial infarction, although methods are available to reduce the impact of this issue [14].

When it comes to heart vascularisation, detailed anatomical studies show that the pig is by far the best model. In fact not only the coronary anatomy but even the poor subendocardial to epicardial collateral network of the swine heart are very similar to that of humans [15]. Minor differences have only been described in the septal arteries: the anterior ones provide most of the irroration in man, whereas in the porcine heart, anterior and posterior arteries share the septal ventricular vascularisation almost equally [16]. Most of the pig studies have been performed using ameroid constrictors leading to a progressive coronary stenosis with late occlusion with consequent myocardial ischemia and ventricular dysfunction, but heart failure could be produced only by using acute coronary occlusion. Such extensive similarities allowed us to perform studies that evaluated the re-establishment of stable collateral networks and improved myocardial perfusion in response to the administration of angiogenic growth factors [17].

When postinfarction congestive heart failure is to be studied, the sheep is a better model because lack of collateral blood flow to the infarcted area, maintenance of normal blood flow to uninfarcted areas, and the moderate size of the infarcted myocardium allow us to faithfully reproduce the three major clinical causes of this pathology [18]. This has greatly contributed to the understanding of differing outcomes dependent on specific locations of MI creation [19]. Limitations of working with sheep, being ruminants, derive from their gastrointestinal anatomy and thoracic contours that are substantially different from those of monogastric species. This can make certain imaging approaches difficult, specifically ultrasonic imaging that requires an invasive approach as opposed to transthoracic imaging applicable to other models.

\section{The many stem cells available for heart regeneration}

A distinct characteristic of cardiogenic stem cells is that they can be either endogenous or derive from outside the heart itself, can originate as the natural course of their differentiation programme (e.g., embryonic stem cells) or can be the result of specific inductive conditions (e.g., mesenchymal stem cells). Why so many cell types have a cardiogenic potential, at least in vitro, is not clear. This can reflect the requirement for a specific precursor of each of the cell types that are found in the heart including cardiomyocytes, endothelial cells, smooth muscle cells, conduction system cells as well as neurons, or it can simply mimic the process of cardiac differentiation, where a variety of progenitor cells contribute to new cardiac tissue at different stages of embryonic development.

The following are the better characterized cardiac exogenous progenitor cells. Mesenchymal stem cells (MSC) are mainly found in the bone marrow stroma and in adipose tissue, are multipotent, can be easily amplified in culture and differentiate efficiently into different cell types including adipocytes, chondrocytes, osteoblasts and endothelial cells [20]. Despite the fact that they differentiate into contracting cardiomyocytes with low efficiency, MSC administration leads to a significant functional improvement and to a lower mortality rate in a canine model of AMI [21]. However, the ability of MSCs to transdifferentiate into cardiomyocytes is highly controversial [22] and their beneficial effect is thought to derive mainly from their influence on neovascularization of the ischemic tissue and their protection of resident cells [23]. This property, together with their low immunogenicity [24], make MSCs an efficient cellular vehicle for delivering therapeutic substances to the myocardial lesion [25], promoting their use in allogeneic recipients as well.

Skeletal myoblasts, or satellite cells, are the endogenous stem cell population that efficiently maintains homeostasis in skeletal muscle [26]; they are easy to isolate and propagate in vitro. The similarity between skeletal and cardiac muscle cells suggests that satellite cells should be able to switch towards a cardiomyocyte fate once inside the ventricular tissue. However, even if the administration of satellite cells brings the formation of contracting cells, these largely fail to form intercalated disks and appropriate gap junctions with resident cardiomyocytes [27], often causing serious arrhythmias [28].

Bone marrow-derived progenitor cells (BMPCs) are a heterogeneous mixture that comprises endothelial progenitor cells, mononuclear bone marrow cells and CD34-positive cells. BMPCs have been administered to patients affected by acute myocardial infarction or chronic ischemic heart failure with positive effects on cardiac function and documented safety of this thera- 
peutic approach [29]. These cells constitute an appealing source of cardiac precursors because they can be easily collected from bone marrow aspirates or from the peripheral blood. However, BMPCs plasticity and their ability to acquire the cardiomyocyte lineage after infarction is still controversial [30].

Embryonic stem cells (ESC) and, more recently, induced Pluripotent Stem cells (iPS) have been shown to be able to differentiate in vitro into genuine cardiomyocytes and supportive cardiac cells $[31,32]$ as well as to integrate into heart tissue, improving cardiac function [33,34]. However, ESC and iPS also have disadvantages that may limit their use in clinical settings. Possibly the most serious is their propensity to develop teratomas, tumors that contain a variety of different tissues [35]. Furthermore ES/iPS cells differentiate into heterogeneous populations, where cardiac cells represent approximately $1 \%$. It is therefore necessary to improve this efficiency and to obtain heart specialized cell types, such as ventricular and atrial myocytes, or pacemaker and conduction system cells [36]. Finally, grafted ESC form a syncytium but usually become separated from the myocardium by a layer of fibrotic tissue. This prevents a proper electrical coupling, and is a major risk factor for arrhythmias [37]. Most of these limitations, however, could be overcome by the recently reported derivation of induced cardiomyocytes (iCM) [38]. These new cells were obtained by transfecting postnatal cardiac fibroblasts (the most common cell type in the heart) with a combination of three developmental transcription factors (i.e., Gata4, Mef2c and Tbx5). Induced cardiomyocytes express cardiacspecific markers, have a global gene expression profile similar to cardiomyocytes and contract spontaneously. Since the reprogramming protocol does not involve, in this instance, a pluripotent embryonic-like status, these cells should not have the propensity to develop teratomas. Furthermore, should it be possible to reprogram the heart fibroblasts in situ, the functional integration of the newly generated cardiomyocytes will be greatly enhanced.

The heart has always been considered a terminally differentiated postmitotic organ, but recent studies demonstrated that cardiac homeostasis is maintained by a local cell population known as resident cardiac stem cells (CSCs) [39] confirming in mammals what was already known in teleost fish and amphibians, where heart regeneration is a much more evident phenomena [40]. As mentioned above, CSCs are also a heterogeneous group composed of different members mostly lacking unequivocal markers for their identification.
Side population (SP) cells are a typical example, being identified by their inability to take up staining by the vital dyes Hoechst 3342 and rhodamine 123. SP cells are multipotent and have been identified not only in the heart but also in the bone marrow, skeletal muscle and adipose tissue [41]. Following a myocardial infarction, the number of SP cells in the mouse heart increases through proliferation of resident SP cells, as well as homing of BM-derived SP cells [42].

Cells positive to c-Kit surface antigen are located in small clusters within the ventricles and atria of the adult heart and, when transplanted in an injured cardiac tissue, differentiate into cardiomyocytes, endothelial cells and smooth muscle cells $[43,44]$. CSCs also include cells expressing stem cell antigen 1 (SCA-1) but not $\mathrm{c}-\mathrm{Kit}$, a rare cell population SCA- $1^{+} / \mathrm{cKit}^{+}$as well as another Sca- $1^{+} / \mathrm{CD} 31^{+}$cell type. Cells derived from the secondary heart field during embryonic development persist, in small numbers, in the adult organ and are marked by the expression of Isl1. Isl $1^{+}$cells can give rise to cardiomyocytes, smooth muscle and endothelial cells [45].

CSCs are derived from small heart biopsies through a delicate enzymatic digestion that releases round cells which in turn form round bodies in suspension culture, called cardiospheres. Upon transplantation into damaged heart tissue, these cells differentiate into vascular and cardiac cells and exert positive paracrine effects [46].

Finally, both endothelial [47] and epicardial [48] cells become activated after injury and give rise to cardiac, vascular and myofibroblast/smooth muscle cells resuming their capacity during development.

\section{Which cardiac stem cells are available in large animal models, and do they actually work?}

After having described the morphological and functional similarities that make large animal models a well established and useful tool in cardiac research, and having described the different kind of cardiogenic stem cells, we now summarize which cells are available in the different species (Fig. 1).

Rabbit was one of the first species used to investigate the possibility of myocardial tissue regeneration. Early work tested the use of autologous transplantation of skeletal myoblasts (satellite cells) and observed the capacity of these cells to partially restore the function of damaged tissue [49,50]. More recently, rabbit has been used to investigate bone marrow-derived stem cells (BMCs). Results indicated that autologous BMCs 

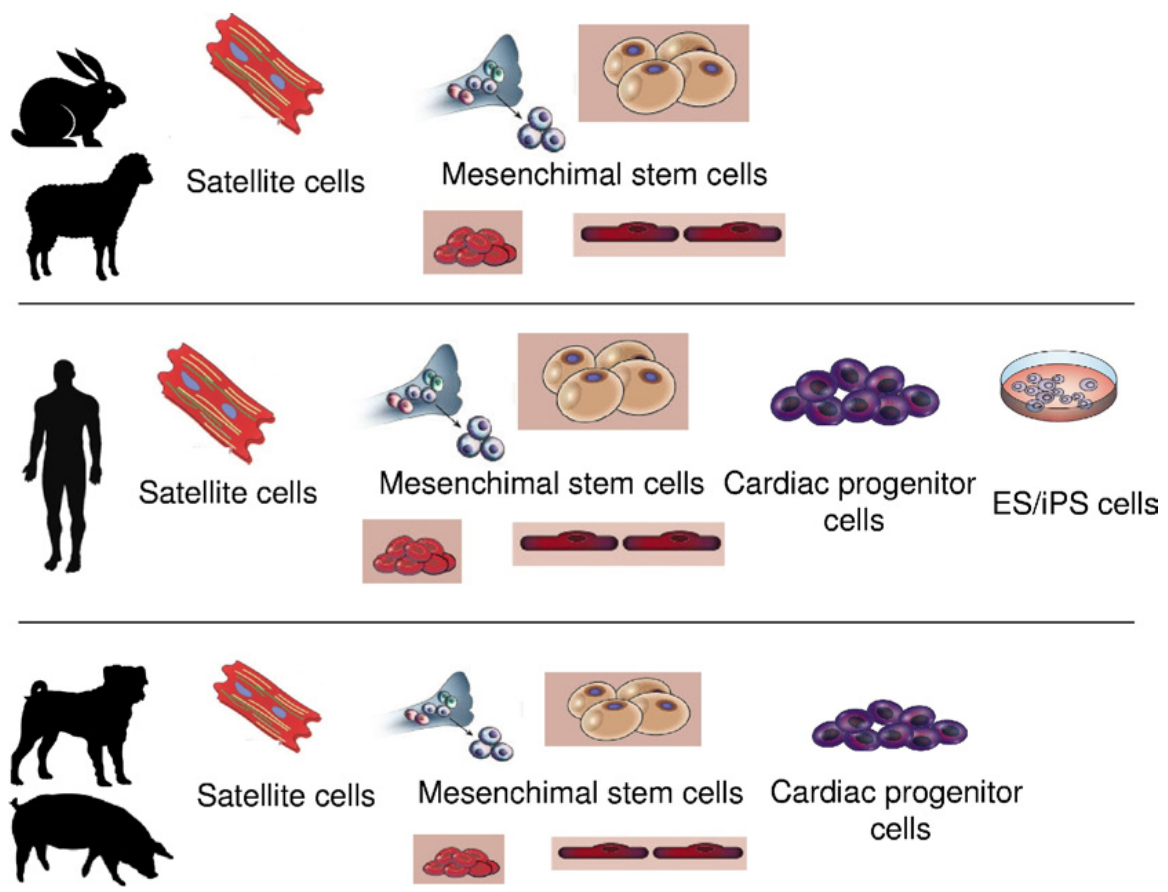

Fig. 1. Human cardiac stem cells can be either endogenous or derive from outside the heart itself like satellite cells, different kind of mesenchymal stem cells, or embryonic/iP stem cells. However, whereas satellite cells and many different kind of mesenchymal cell types are available in every large animal model species, cardiac progenitor cells have been derived only in dog and pig. At present no ESC/iPS cells are available in any of these species.

improve global contractility and enhance myocardial remote capillary density and collagen content even if BMCs failed to transdifferentiate into new cardiomyocytes [51]. A more specialized cell population, bone marrow mononuclear cells (BMMNCs), has also been derived in rabbit, and used for intracoronary injection resulting in a substantial delay of collagen metabolism and a decrease of the myocardial collagen volume fraction [52]. Rabbit MSCs are also available and provide an effective improvement of cardiac function [53].

Dog cardiac stem cells are available from different sources. Furthermore, in this species skeletal muscle satellite cells were one of the first cell types to be isolated and tested for their capacity to regenerate damaged myocardial tissue providing proof of principle studies on the safety and efficacy of this method $[54,55]$.

One of the most investigated cell type is the bone marrow-derived MSC that has the important advantage of eliciting a very mild immune response and can therefore be used in heterologous transplants with no need of immunosuppressive treatments [21]. Dog MSCs can also undergo cardiomyogenic specification by ex vivo pre-treatment with specific growth factors, thus improving their regenerative properties [56]. These cells have positive effects when administered after both an acute or chronic myocardial ischaemia [21,57].
Very recent data demonstrate that it is possible to derive dog endothelial progenitor cells and, thanks to the anatomical similarities described above, it was possible to demonstrate that these cells can also be administered effectively following subendocardial injections, a clinically more practical route of administration [58].

The dog heart also possesses an endogenous cardiac stem cell (CSC) pool characterized by undifferentiated cells that are self-renewing, clonogenic and multipotent [59]. As described for the corresponding human cells [43] canine CSCs express c-kit, MDR1, and Sca-1-like antigens suggesting that results obtained in the dog are likely to be relevant to man. Dog CSCs can also form three-dimensional cell aggregates, so called cardiospheres, whose regenerative properties are currently under investigation [60].

Sheep mesenchymal stem cells can be easily derived as in other large animal models [61]. In this species the perivascular STRO-3 positive mesenchymal precursor cells (MPCs), a small fraction of mesenchymal stem cells that demonstrate an extensive capacity for proliferation and differentiation, have also been identified and tested for their regenerative properties [62].

Sheep is often used to study the possibility to use MSC for cardiac valve regeneration in association with bioabsorbable valved patches $[63,64]$. Bone marrow mononuclear cells (BMMC) have been used to create in 
vitro tissue-engineered heart valves based on a decellularized porcine scaffold then tested in autologous transplantats [65]. Endothelial progenitor cells (EPCs) have also been used as a cell source for the creation of tissue-engineered heart valves in sheep [66].

Skeletal myoblast can be derived and propagated in vitro in sheep as described in other species and large areas of grafted cells can be found within the myocardial lesion, however the cells maintain the histological features of well-differentiated skeletal muscle cells [67].

Pig cardiogenic stem cells are the most studied. In this species all sort of bone marrow-derived stem cells are currently available. These include BM-derived mononuclear cells (BM-MNCs) [68-70], peripheral blood mononuclear cells (PB-MNCs) [71,72] and BMderived mesenchymal stem cells [73]. Bone marrowderived MSC have been magnetically labeled in order to develop non-invasive methods for studying the engraftment based on magnetic resonance imaging (MRI) [74,75]. Pig MSC were used also to explore new delivery methods like a patch of a fibrin matrix seeded with autologous cells [76]. As it was observed in other species, pig MSCs can be prepared from an allogeneic donor without being rejected, confirming that these cells have a major practical advantage for their widespread application in a clinical setting [77] and are also being tested for proving the safety of an "off-the-shelf" cellular cardiomyoplasty strategy [78]. In addition, direct intramyocardial injection of MSCs results in successful engraftment and differentiation into cardiomyocytes and endothelial cells and preserves left ventricular function in acute [79] and chronic myocardial lesions [80].

Cardiogenic stem cells have been derived from pig adipose tissue (ADSCs) and can engraft in the infarcted region 4 weeks after transcatheter intracoronary cell transplantation improving cardiac function and perfusion via angiogenesis with an efficiency comparable to that of bone marrow-derived stem cells [81].

Pig amniotic fluid-derived mesenchymal cells (AFC) are also available. However, when autotransplanted in a porcine model of acute myocardial infarction, AFC are able to transdifferentiate to cells of vascular cell lineages but not to cardiomyocytes [82].

Resident cardiac stem cells (CSC) can be derived from pig endomyocardial specimens. When pig CSCs are grown in primary culture they form cardiospheres that can be plated to obtain cardiosphere-derived cells (CDCs). CDCs are cardiogenic in vitro as indicated by spontaneous intracellular calcium transients and action potentials as well as fast, inward sodium currents, however, cardiospheres and CDCs do not spontaneously contract [46].

We have recently isolated a different type of CSC, the cardiac mesoangioblasts (MABs), from atrium and aorta explants of the adult pig. Originally identified in mouse [83] and human hearts [84,85], MABs are committed to the cardiac lineage and differ from other stem/progenitor cells types because of marker expression, isolation method, and differentiation potency. They have been characterized for the expression of stemness markers and for the expression of early and late cardiac markers, endothelial markers and muscular markers. Pig MABS differentiate into mesodermal cell types, and can give rise to functional cardiomyocytes (ISSCR 2009).

\section{Delivery methods}

The aim of cell therapy is to reach the region of interest through the best way. Traditionally in heart cell therapy three ways have been adopted: arterial coronary administration, percutaneous endocardial or direct transmyocardial injection [86,87]. Experimental data demonstrate that MSCs and progenitors cells can reach the diseased area through the intracoronary infusion even though high dose could obstruct the microcirculation with consequent embolic myocardial episodes. Endo- and epicardial routes seem to remain the best way to reach the target even if the epicardial cell administration remain more invasive and could be performed during open heart surgery [88].

\section{Conclusions}

The development of an effective regenerative therapy of the heart is not likely to be achieved in the near future since clinical and animal studies show that true cardiac regeneration does involve more complex aspects than injecting the right type of cells in the right place [3].

Large animal models have a well established role in cardiovascular research and the derivation of different types of cardiogenic stem cells in different species indicated that these models can certainly provide a substantial contribution to the development of cell therapies. Mesenchymal stem cells of different origin have proved to be readily available in these species and showed the same properties of their human counterpart. More limited, at present, are the data available on cardiac resident stem cells, but promising results are 
being achieved. On the contrary, the derivation of bona fide embryonic stem cells is still elusive in these species, making large animal models not available for this very promising cell type. However the recent derivation of iPS in pig $[89,90]$ may soon be able to overcome this limitation.

\section{References}

[1] Lopez AD, Mathers CD, Ezzati M, Jamison DT, Murray CJ. Global and regional burden of disease and risk factors, 2001: systematic analysis of population health data. Lancet 2006;367: 1747-57.

[2] Gaziano TA, Bitton A, Anand S, Abrahams-Gessel S, Murphy A. Growing epidemic of coronary heart disease in low- and middle-income countries. Curr Probl Cardiol 2010;35:72-115.

[3] Segers VF, Lee RT. Stem-cell therapy for cardiac disease. Nature 2008;451:937-42.

[4] Dixon JA, Spinale FG. Large animal models of heart failure: a critical link in the translation of basic science to clinical practice. Circ Heart Fail 2009;2:262-71.

[5] Blankesteijn WM, Creemers E, Lutgens E, Cleutjens JP, Daemen MJ, Smits JF. Dynamics of cardiac wound healing following myocardial infarction: observations in genetically altered mice. Acta Physiol Scand 2001;173:75-82.

[6] Rakusan K, Nagai J. Morphometry of arterioles and capillaries in hearts of senescent mice. Cardiovasc Res 1994;28:969-72.

[7] Stoker ME, Gerdes AM, May JF. Regional differences in capillary density and myocyte size in the normal human heart. Anat Rec 1982;202:187-91.

[8] Doevendans PA, Daemen MJ, de Muinck ED, Smits JF. Cardiovascular phenotyping in mice. Cardiovasc Res 1998; 39:34-49.

[9] Swynghedauw B. Developmental and functional adaptation of contractile proteins in cardiac and skeletal muscles. Physiol Rev 1986;66:710-71.

[10] Liu W, Ashford MW, Chen J, Watkins MP, Williams TA, Wickline SA, Yu X. MR tagging demonstrates quantitative differences in regional ventricular wall motion in mice, rats, and men. Am J Physiol Heart Circ Physiol 2006;291:H2515-21.

[11] Reimer KA, Jennings RB. The "wavefront phenomenon" of myocardial ischemic cell death. II. Transmural progression of necrosis within the framework of ischemic bed size (myocardium at risk) and collateral flow. Lab Invest 1979;40:633-44.

[12] Jugdutt BI, Menon V. Valsartan-induced cardioprotection involves angiotensin II type 2 receptor upregulation in dog and rat models of in vivo reperfused myocardial infarction. J Card Fail 2004;10:74-82.

[13] White FC, Roth DM, Bloor CM. The pig as a model for myocardial ischemia and exercise. Lab Anim Sci 1986;36: 351-6.

[14] Mukherjee R, Brinsa TA, Dowdy KB, Scott AA, Baskin JM, Deschamps AM, Lowry AS, Escobar GP, Lucas DG, Yarbrough WM, Zile MR, Spinale FG. Myocardial infarct expansion and matrix metalloproteinase inhibition. Circulation 2003;107: 618-25.

[15] Weaver ME, Pantely GA, Bristow JD, Ladley HD. A quantitative study of the anatomy and distribution of coronary arteries in swine in comparison with other animals and man. Cardiovasc Res 1986;20:907-17.
[16] Bertho E, Gagnon G. A Comparative Study in Three Dimension of the Blood Supply of the Normal Interventricular Septum in Human, Canine, Bovine, Procine, Ovine and Equine Heart. Dis Chest 1964;46:251-62.

[17] Lu H, Xu X, Zhang M, Cao R, Brakenhielm E, Li C, Lin H, Yao G, Sun H, Qi L, Tang M, Dai H, Zhang Y, Su R, Bi Y, Cao Y. Combinatorial protein therapy of angiogenic and arteriogenic factors remarkably improves collaterogenesis and cardiac function in pigs. Proc Natl Acad Sci USA 2007;104:12140-5.

[18] Myocardial infarct expansion and matrix metalloproteinase inhibition. Circulation 2003;107:618-25.

[19] Gorman JH, 3rd, Gorman RC, Plappert T, Jackson BM, Hiramatsu Y, St John-Sutton MG, Edmunds LH, Jr. Infarct size and location determine development of mitral regurgitation in the sheep model. J Thorac Cardiovasc Surg 1998;115:615-22.

[20] Pittenger MF, Mackay AM, Beck SC, Jaiswal RK, Douglas R, Mosca JD, Moorman MA, Simonetti DW, Craig S, Marshak DR. Multilineage potential of adult human mesenchymal stem cells. Science 1999;284:143-7.

[21] Silva GV, Litovsky S, Assad JA, Sousa AL, Martin BJ, Vela D, Coulter SC, Lin J, Ober J, Vaughn WK, Branco RV, Oliveira EM, He R, Geng YJ, Willerson JT, Perin EC. Mesenchymal stem cells differentiate into an endothelial phenotype, enhance vascular density, and improve heart function in a canine chronic ischemia model. Circulation 2005;111:150-6.

[22] Rose RA, Keating A, Backx PH. Do mesenchymal stromal cells transdifferentiate into functional cardiomyocytes? Circ Res 2008;103:e120.

[23] Gnecchi M, Zhang Z, Ni A, Dzau VJ. Paracrine mechanisms in adult stem cell signaling and therapy. Circ Res 2008;103: 1204-19.

[24] Aggarwal S, Pittenger MF. Human mesenchymal stem cells modulate allogeneic immune cell responses. Blood 2005;105: 1815-22.

[25] Boudoulas KD, Hatzopoulos AK. Cardiac repair and regeneration: the Rubik's cube of cell therapy for heart disease. Dis Model Mech 2009;2:344-58.

[26] Buckingham M, Montarras D. Skeletal muscle stem cells. Curr Opin Genet Dev 2008;18:330-6.

[27] Reinecke H, Poppa V, Murry CE. Skeletal muscle stem cells do not transdifferentiate into cardiomyocytes after cardiac grafting. J Mol Cell Cardiol 2002;34:241-9.

[28] Leobon B, Garcin I, Menasche P, Vilquin JT, Audinat E, Charpak S. Myoblasts transplanted into rat infarcted myocardium are functionally isolated from their host. Proc Natl Acad Sci USA 2003;100:7808-11.

[29] Martin-Rendon E, Brunskill SJ, Hyde CJ, Stanworth SJ, Mathur A, Watt SM. Autologous bone marrow stem cells to treat acute myocardial infarction: a systematic review. Eur Heart J 2008; 29:1807-18.

[30] Hosoda T, Kajstura J, Leri A, Anversa P. Mechanisms of myocardial regeneration. Circ J 2010;74:13-7.

[31] Passier R, van Laake LW, Mummery CL. Stem-cell-based therapy and lessons from the heart. Nature 2008;453:322-9.

[32] Narazaki G, Uosaki H, Teranishi M, Okita K, Kim B, Matsuoka S, Yamanaka S, Yamashita JK. Directed and systematic differentiation of cardiovascular cells from mouse induced pluripotent stem cells. Circulation 2008;118:498-506.

[33] Laflamme MA, Chen KY, Naumova AV, Muskheli V, Fugate JA, Dupras SK, Reinecke H, Xu C, Hassanipour M, Police S, O'Sullivan C, Collins L, Chen Y, Minami E, Gill EA, Ueno S, Yuan C, Gold J, Murry CE. Cardiomyocytes derived from 
human embryonic stem cells in pro-survival factors enhance function of infarcted rat hearts. Nat Biotech 2007;25:1015.

[34] Yan P, Nagasawa A, Uosaki H, Sugimoto A, Yamamizu K, Teranishi M, Matsuda H, Matsuoka S, Ikeda T, Komeda M, Sakata R, Yamashita JK. Cyclosporin-A potently induces highly cardiogenic progenitors from embryonic stem cells. Biochem Biophys Res Commun 2009;379:115-20.

[35] Nussbaum J. Transplantation of undifferentiated murine embryonic stem cells in the heart: teratoma formation and immune response. FASEB J 2007;21:1345.

[36] Behfar A, Faustino RS, Arrell DK, Dzeja PP, Perez-Terzic C, Terzic A. Guided stem cell cardiopoiesis: discovery and translation. J Mol Cell Cardiol 2008;45:523-9.

[37] Laflamme MA, Zbinden S, Epstein SE, Murry CE. Cell-based cardiac repair: pathophysiologic mechanisms. Annu Rev Pathol Mech Dis 2007;2:307.

[38] Ieda M, Fu J-D, Delgado-Olguin P, Vedantham V, Hayashi Y, Bruneau BG, Srivastava D. Direct Reprogramming of Fibroblasts into Functional Cardiomyocytes by Defined Factors. Cell 2010;142:375-86.

[39] Torella D, Ellison GM, Karakikes I, Nadal-Ginard B. Growthfactor-mediated cardiac stem cell activation in myocardial regeneration. Nat Clin Pract Cardiovasc Med 2007;4 Suppl 1:S46-51.

[40] Ausoni S, Sartore S. From fish to amphibians to mammals: in search of novel strategies to optimize cardiac regeneration. The Journal of Cell Biology 2009;184:357-64.

[41] Bouchet-Marquis C, Dubochet J, Fakan S. Cryoelectron microscopy of vitrified sections: a new challenge for the analysis of functional nuclear architecture. Histochem Cell Biol 2006;125: $43-51$.

[42] Mouquet F, Pfister O, Jain M, Oikonomopoulos A, Ngoy S, Summer R, Fine A, Liao R. Restoration of cardiac progenitor cells after myocardial infarction by self-proliferation and selective homing of bone marrow-derived stem cells. Circ Res 2005; 97:1090-2.

[43] Beltrami AP, Barlucchi L, Torella D, Baker M, Limana F, Chimenti S, Kasahara H, Rota M, Musso E, Urbanek K, Leri A, Kajstura J, Nadal-Ginard B, Anversa P. Adult cardiac stem cells are multipotent and support myocardial regeneration. Cell 2003; 114:763-76.

[44] Rota M, Padin-Iruegas ME, Misao Y, De Angelis A, Maestroni S, Ferreira-Martins J, Fiumana E, Rastaldo R, Arcarese ML, Mitchell TS, Boni A, Bolli R, Urbanek K, Hosoda T, Anversa P, Leri A, Kajstura J. Local activation or implantation of cardiac progenitor cells rescues scarred infarcted myocardium improving cardiac function. Circ Res 2008;103:107-16.

[45] Laugwitz KL, Moretti A, Caron L, Nakano A, Chien KR. Islet1 cardiovascular progenitors: a single source for heart lineages? Development 2008;135:193-205.

[46] Smith RR, Barile L, Cho HC, Leppo MK, Hare JM, Messina E, Giacomello A, Abraham MR, Marban E. Regenerative potential of cardiosphere-derived cells expanded from percutaneous endomyocardial biopsy specimens. Circulation 2007;115:896908.

[47] Zeisberg EM, Tarnavski O, Zeisberg M, Dorfman AL, McMullen JR, Gustafsson E, Chandraker A, Yuan X, Pu WT, Roberts AB, Neilson EG, Sayegh MH, Izumo S, Kalluri R. Endothelial-to-mesenchymal transition contributes to cardiac fibrosis. Nat Med 2007;13: 952-61.

[48] van Tuyn J, Atsma DE, Winter EM, van der Velde-van Dijke I, Pijnappels DA, Bax NA, Knaan-Shanzer S, Gittenberger-de
Groot AC, Poelmann RE, van der Laarse A, van der Wall EE, Schalij MJ, de Vries AA. Epicardial cells of human adults can undergo an epithelial-to-mesenchymal transition and obtain characteristics of smooth muscle cells in vitro. Stem Cells 2007;25:271-8.

[49] Taylor DA, Atkins BZ, Hungspreugs P, Jones TR, Reedy MC, Hutcheson KA, Glower DD, Kraus WE. Regenerating functional myocardium: improved performance after skeletal myoblast transplantation. Nat Med 1998;4:929-33.

[50] Taylor DA, Silvestry SC, Bishop SP, Annex BH, Lilly RE, Glower DD, Kraus WE. Delivery of primary autologous skeletal myoblasts into rabbit heart by coronary infusion: a potential approach to myocardial repair. Proc Assoc Am Physicians 1997;109:245-53.

[51] Garbade J, Dhein S, Lipinski C, Aupperle H, Arsalan M, Borger MA, Barten MJ, Lehmann S, Walther T, Mohr F-W. Bone Marrow-Derived Stem Cells Attenuate Impaired Contractility and Enhance Capillary Density in a Rabbit Model of Doxorubicin-Induced Failing Hearts. J Card Surg 2009;24:591-9.

[52] Jin B, Luo XP, Ni HC, Li Y, Shi HM. Cardiac matrix remodeling following intracoronary cell transplantation in dilated cardiomyopathic rabbits. Mol Biol Rep 2010;37:3037-42.

[53] Xu Y-L, Gao Y-H, Liu Z, Tan K-B, Hua X, Fang Z-Q, Wang Y-L, Wang Y-J, Xia H-M, Zhuo Z-X. Myocardium-targeted transplantation of mesenchymal stem cells by diagnostic ultrasound-mediated microbubble destruction improves cardiac function in myocardial infarction of New Zealand rabbits. Int J Cardiol 2010;138:182-95.

[54] Yoon PD, Kao RL, Magovern GJ. Myocardial regeneration. Transplanting satellite cells into damaged myocardium. Tex Heart Inst J 1995;22:119-25.

[55] Chiu RC, Zibaitis A, Kao RL. Cellular cardiomyoplasty: myocardial regeneration with satellite cell implantation. Ann Thorac Surg 1995;60:12-8.

[56] Bartunek J, Croissant JD, Wijns W, Gofflot S, de Lavareille A, Vanderheyden M, Kaluzhny Y, Mazouz N, Willemsen P, Penicka M, Mathieu M, Homsy C, De Bruyne B, McEntee K, Lee IW, Heyndrickx GR. Pretreatment of adult bone marrow mesenchymal stem cells with cardiomyogenic growth factors and repair of the chronically infarcted myocardium. Am J Physiol Heart Circ Physiol 2007;292:H1095-104.

[57] Vulliet PR, Greeley M, Halloran SM, MacDonald KA, Kittleson MD. Intra-coronary arterial injection of mesenchymal stromal cells and microinfarction in dogs. Lancet 2004;363:783-4.

[58] Mitchell AJ, Sabondjian E, Sykes J, Deans L, Zhu W, Lu X, Feng Q, Prato FS, Wisenberg G. Comparison of initial cell retention and clearance kinetics after subendocardial or subepicardial injections of endothelial progenitor cells in a canine myocardial infarction model. J Nucl Med 2010;51:413-7.

[59] Linke A, Muller P, Nurzynska D, Casarsa C, Torella D, Nascimbene A, Castaldo C, Cascapera S, Bohm M, Quaini F, Urbanek K, Leri A, Hintze TH, Kajstura J, Anversa P. Stem cells in the dog heart are self-renewing, clonogenic, and multipotent and regenerate infarcted myocardium, improving cardiac function. Proc Natl Acad Sci USA 2005;102:8966-71.

[60] Bartosh TJ, Wang Z, Rosales AA, Dimitrijevich SD, Roque RS. 3D-model of adult cardiac stem cells promotes cardiac differentiation and resistance to oxidative stress. J Cell Biochem 2008;105:612-23.

[61] Weir, Morel-Kopp MC, Gill A, Tinworth K, Ladd L, Hunyor SN, Ward C. Mesenchymal stem cells: isolation, characterisa- 
tion and in vivo fluorescent dye tracking. Heart Lung Circ 2008;17:395-403.

[62] Hamamoto H, Gorman JH, 3rd, Ryan LP, Hinmon R, Martens TP, Schuster MD, Plappert T, Kiupel M, St John-Sutton MG, Itescu S, Gorman RC. Allogeneic mesenchymal precursor cell therapy to limit remodeling after myocardial infarction: the effect of cell dosage. Ann Thorac Surg 2009;87:794-801.

[63] Kalfa D, Bel A, Chen-Tournoux A, Della Martina A, Rochereau P, Coz C, Bellamy V, Bensalah M, Vanneaux V, Lecourt S, Mousseaux E, Bruneval P, Larghero J, Menasche P. A polydioxanone electrospun valved patch to replace the right ventricular outflow tract in a growing lamb model. Biomaterials 2010; 31:4056-63.

[64] Sutherland FW, Perry TE, Yu Y, Sherwood MC, Rabkin E, Masuda Y, Garcia GA, McLellan DL, Engelmayr GC, Jr., Sacks MS, Schoen FJ, Mayer JE, Jr.From stem cells to viable autologous semilunar heart valve. Circulation 2005;111:2783-91.

[65] Vincentelli A, Wautot F, Juthier F, Fouquet O, Corseaux D, Marechaux S, Le Tourneau T, Fabre O, Susen S, Van Belle E, Mouquet F, Decoene C, Prat A, Jude B. In vivo autologous recellularization of a tissue-engineered heart valve: are bone marrow mesenchymal stem cells the best candidates? J Thorac Cardiovasc Surg 2007;134:424-32.

[66] Sales VL, Mettler BA, Engelmayr GC, Jr., Aikawa E, Bischoff J, Martin DP, Exarhopoulos A, Moses MA, Schoen FJ, Sacks MS, Mayer JE, Jr. Endothelial progenitor cells as a sole source for ex vivo seeding of tissue-engineered heart valves. Tissue Eng Part A 2010;16:257-67.

[67] Ghostine S, Carrion C, Souza LC, Richard P, Bruneval P, Vilquin JT, Pouzet B, Schwartz K, Menasche P, Hagege AA. Long-term efficacy of myoblast transplantation on regional structure and function after myocardial infarction. Circulation 2002;106:I131-36.

[68] Kamihata H, Matsubara H, Nishiue T, Fujiyama S, Tsutsumi Y, Ozono R, Masaki H, Mori Y, Iba O, Tateishi E, Kosaki A, Shintani S, Murohara T, Imaizumi T, Iwasaka T. Implantation of bone marrow mononuclear cells into ischemic myocardium enhances collateral perfusion and regional function via side supply of angioblasts, angiogenic ligands, and cytokines. Circulation 2001;104:1046-52.

[69] Bhakta S, Greco NJ, Finney MR, Scheid PE, Hoffman RD, Joseph ME, Banks JJ, Laughlin MJ, Pompili VJ. The safety of autologous intracoronary stem cell injections in a porcine model of chronic myocardial ischemia. J Invasive Cardiol 2006;18: $212-8$.

[70] Makela J, Ylitalo K, Lehtonen S, Dahlbacka S, Niemela E, Kiviluoma K, Rimpilainen J, Alaoja H, Paavonen T, Lehenkari $\mathrm{P}$, Juvonen T, Anttila V. Bone marrow-derived mononuclear cell transplantation improves myocardial recovery by enhancing cellular recruitment and differentiation at the infarction site. J Thorac Cardiovasc Surg 2007;134:565-73.

[71] Kamihata H, Matsubara H, Nishiue T, Fujiyama S, Amano K, Iba O, Imada T, Iwasaka T. Improvement of collateral perfusion and regional function by implantation of peripheral blood mononuclear cells into ischemic hibernating myocardium. Arterioscler Thromb Vasc Biol 2002;22:1804-10.

[72] Doyle B, Sorajja P, Hynes B, Kumar AH, Araoz PA, Stalboerger PG, Miller D, Reed C, Schmeckpeper J, Wang S, Liu C, Terzic A, Kruger D, Riederer S, Caplice NM. Progenitor cell therapy in a porcine acute myocardial infarction model induces cardiac hypertrophy, mediated by paracrine secretion of car- diotrophic factors including TGFbeta1. Stem Cells Dev 2008; 17:941-51.

[73] Pak HN, Qayyum M, Kim DT, Hamabe A, Miyauchi Y, Lill MC, Frantzen M, Takizawa K, Chen LS, Fishbein MC, Sharifi BG, Chen PS, Makkar R. Mesenchymal stem cell injection induces cardiac nerve sprouting and increased tenascin expression in a Swine model of myocardial infarction. J Cardiovasc Electrophysiol 2003;14:841-8.

[74] Kraitchman DL, Heldman AW, Atalar E, Amado LC, Martin BJ, Pittenger MF, Hare JM, Bulte JW. In vivo magnetic resonance imaging of mesenchymal stem cells in myocardial infarction. Circulation 2003;107:2290-3.

[75] He G, Zhang H, Wei H, Wang Y, Zhang X, Tang Y, Wei Y, Hu $\mathrm{S}$. In vivo imaging of bone marrow mesenchymal stem cells transplanted into myocardium using magnetic resonance imaging: a novel method to trace the transplanted cells. Int J Cardiol 2007;114:4-10.

[76] Liu J, Hu Q, Wang Z, Xu C, Wang X, Gong G, Mansoor A, Lee J, Hou M, Zeng L, Zhang JR, Jerosch-Herold M, Guo T, Bache RJ, Zhang J. Autologous stem cell transplantation for myocardial repair. Am J Physiol Heart Circ Physiol 2004;287:H50111.

[77] Amado LC, Saliaris AP, Schuleri KH, St John M, Xie JS, Cattaneo S, Durand DJ, Fitton T, Kuang JQ, Stewart G, Lehrke S, Baumgartner WW, Martin BJ, Heldman AW, Hare JM. Cardiac repair with intramyocardial injection of allogeneic mesenchymal stem cells after myocardial infarction. Proc Natl Acad Sci USA 2005;102:11474-9.

[78] Poh KK, Sperry E, Young RG, Freyman T, Barringhaus KG, Thompson CA. Repeated direct endomyocardial transplantation of allogeneic mesenchymal stem cells: safety of a high dose, "off-the-shelf", cellular cardiomyoplasty strategy. Int J Cardiol 2007;117:360-4.

[79] Makkar RR, Price MJ, Lill M, Frantzen M, Takizawa K, Kleisli T, Zheng J, Kar S, McClelan R, Miyamota T, Bick-Forrester J, Fishbein MC, Shah PK, Forrester JS, Sharifi B, Chen PS, Qayyum M. Intramyocardial injection of allogenic bone marrow-derived mesenchymal stem cells without immunosuppression preserves cardiac function in a porcine model of myocardial infarction. J Cardiovasc Pharmacol Ther 2005;10:225-33.

[80] Schuleri KH, Feigenbaum GS, Centola M, Weiss ES, Zimmet JM, Turney J, Kellner J, Zviman MM, Hatzistergos KE, Detrick B, Conte JV, McNiece I, Steenbergen C, Lardo AC, Hare JM. Autologous mesenchymal stem cells produce reverse remodelling in chronic ischaemic cardiomyopathy. Eur Heart J 2009; 30:2722-32.

[81] Valina C, Pinkernell K, Song YH, Bai X, Sadat S, Campeau RJ, Le Jemtel TH, Alt E. Intracoronary administration of autologous adipose tissue-derived stem cells improves left ventricular function, perfusion, and remodelling after acute myocardial infarction. Eur Heart J 2007;28:2667-77.

[82] Sartore S, Lenzi M, Angelini A, Chiavegato A, Gasparotto L, De Coppi P, Bianco R, Gerosa G. Amniotic mesenchymal cells autotransplanted in a porcine model of cardiac ischemia do not differentiate to cardiogenic phenotypes. Eur J Cardiothorac Surg 2005;28:677-84.

[83] Galvez BG, Sampaolesi M, Barbuti A, Crespi A, Covarello D, Brunelli S, Dellavalle A, Crippa S, Balconi G, Cuccovillo I, Molla F, Staszewsky L, Latini R, Difrancesco D, Cossu G. Cardiac mesoangioblasts are committed, self-renewable progenitors, associated with small vessels of juvenile mouse ventricle. Cell Death Differ 2008;15:1417-28. 
[84] Barbuti A, Galvez BG, Crespi A, Scavone A, Baruscotti M, Brioschi C, Cossu G, DiFrancesco D. Mesoangioblasts from ventricular vessels can differentiate in vitro into cardiac myocytes with sinoatrial-like properties. J Mol Cell Cardiol 2010;48:415-23.

[85] Galvez BG, Covarello D, Tolorenzi R, Brunelli S, Dellavalle A, Crippa S, Mohammed SA, Scialla L, Cuccovillo I, Molla F, Staszewsky L, Maisano F, Sampaolesi M, Latini R, Cossu G. Human cardiac mesoangioblasts isolated from hypertrophic cardiomyopathies are greatly reduced in proliferation and differentiation potency. Cardiovasc Res 2009;83:707-16.

[86] Pendyala L, Goodchild T, Gadesam RR, Chen J, Robinson K, Chronos N, Hou D. Cellular Cardiomyoplasty and Cardiac Regeneration. Curr Cardiol Rev 2008;4:72-80.
[87] Aicher A, Brenner W, Zuhayra M, et al. Assessment of the tissue distribution of transplanted human endothelial progenitor cells by radioactive labeling. Circulation 2003;107:2134-9.

[88] Vulliet PR, Greeley M, Halloran SM, et al. Intracoronary arterial injection of mesenchymal stromal cells and microinfarction in dogs. Lancet 2004;363:783-4.

[89] Wu Z, Chen J, Ren J, Bao L, Liao J, Cui C, Rao L, Li H, Gu Y, Dai H, Zhu H, Teng X, Cheng L, Xiao L. Generation of pig induced pluripotent stem cells with a drug-inducible system. J Mol Cell Biol 2009;1:46-54.

[90] Roberts RM, Telugu BP, Ezashi T. Induced pluripotent stem cells from swine (Sus scrofa): why they may prove to be important. Cell Cycle 2009;8:3078-81. 